\title{
Basic research and clinical applications of bisphosphonates in bone disease: what have we learned over the last 40 years?
}

\author{
Xiao-Long Xu, Wen-Long Gou, Ai-Yuan Wang, Yu Wang, Quan-Yi Guo, Qiang Lu, Shi-Bi Lu and Jiang Peng*
}

\begin{abstract}
It is now 40 years since bisphosphonates (BPs) were first used in the clinic. So, it is timely to provide a brief review of what we have learned about these agents in bone disease. BPs are bone-specific and have been classified into two major groups on the basis of their distinct molecular modes of action: amino-BPs and non-amino-BPs. The amino-BPs are more potent and they inhibit farnesyl pyrophosphate synthase (FPPS), a key enzyme of the mavalonate/ cholesterol biosynthetic pathway, while the non-amino-BPs inhibit osteoclast activity, by incorporation into non-hydrolyzable analogs of ATP. Both amino-BPs and non-amino-BPs can protect osteoblasts and osteocytes against apoptosis. The BPs are widely used in the clinic to treat various diseases characterized by excessive bone resorption, including osteoporosis, myeloma, bone metastasis, Legg-Perthes disease, malignant hyperparathyroidism, and other conditions featuring bone fragility. This review provides insights into some of the adverse effects of BPs, such as gastric irritation, osteonecrosis of the jaw, atypical femoral fractures, esophageal cancer, atrial fibrillation, and ocular inflammation. In conclusion, this review covers the biochemical and molecular mechanisms of action of BPs in bone, particularly the discovery that BPs have direct anti-apoptotic effects on osteoblasts and osteocytes, and the current situation of BP use in the clinic.
\end{abstract}

Keywords: Bisphosphonate, Pharmacokinetics, Osteoclast, Osteoblast, Osteoporosis

\section{Introduction}

Bone fragility, leading to fractures and disability, is implicated in the pathogenesis of various bone-desorption diseases induced by glucocorticoid excess, sex-steroid deficiency, and tumors. Today, BPs are the first-line treatment for osteoporosis [1], metastatic bone cancer [2], and Legg-Calve-Perthes disease [3]. BPs are bone-specific and have been used widely in the clinic. However, their exact mechanisms of action remain incompletely understood. Moreover, these medications have attracted much attention mainly because their complications and pathophysiological aspects remain unclear.

In the present review, we summarize the biochemical and molecular mechanisms of action of BPs in bone, particularly the discovery of BPs having direct anti-apoptotic effects on osteoblasts and osteocytes $[4,5]$. The prospects and caveats for the clinical use of BPs are also discussed.

\footnotetext{
* Correspondence: pengjiang301@126.com

Institute of Orthopedics, Chinese People's Liberation Army General Hospital, 28 Fuxing Road, Beijing 100853, People's Republic of China
}

\section{Pharmacokinetics \\ Absorption}

BPs are administered intravenously or orally. Oral BPs are absorbed into the bloodstream from the gastrointestinal lumen by two routes: 1) transcellularly, transported through epithelial cells into the blood, and 2) intercellularly, whereby BPs gain access to the circulation via the tight junctions between the epithelial cells [6].

Bioavailability is a measure of the rate and extent to which a drug reaches the systemic circulation. The oral bioavailability of BPs is low. The widely used amino-BPs have an absorption of $\sim 0.7 \%$, and non-amino-BPs appear to have a slightly higher absorption, of $2-2.5 \%$ [7]. Also, oral absorption is impaired in the presence of food and calcium-, magnesium-, or aluminum-containing drinks and is enhanced with elevated gastric $\mathrm{pH}[6,8,9]$. If the drug is taken with a meal, the absorption may be reduced to zero [10]. Thus, food may have a marked influence on the absorption of BPs. For example, patients are 
recommended to take their daily dose of oral BPs, such as alendronate, at least $30 \mathrm{~min}$ before breakfast [11].

\section{Distribution of BPs \\ Extra-skeletal}

Previous studies of radio-labeled compounds showed that BPs are taken up and adsorbed in to bone primarily, but some also goes to soft tissues, such as the liver, kidney, and spleen $[12,13]$. The distribution of BPs in extraskeletal tissue differs, with potential differences in plasma protein binding and kidney concentrations. These differences in distribution may explain, in part, the direct effects of BPs on tumor cells in some studies [14].

\section{Distribution in bone}

The skeletal distribution and retention of BPs are essential to their effects on bone. Although the uptake and distribution of BPs have been investigated extensively, in vivo and in vitro, knowledge in humans is incomplete. The amount of BP taken up by bone during the first passage is difficult to quantify. Moreover, the precise route of transfer of BPs from the systemic circulation to bone remains elusive. The distribution in bone is not homogeneous, with the use of ${ }^{14} \mathrm{C}$ and ${ }^{99} \mathrm{mTc}$-labeled BPs in animals and humans, respectively. Studies investigating the important steps in the distribution of the BPs in properly performed human studies is necessary. Additionally, some evidence suggests that BPs bind preferentially to bones with high turnover. For example, the uptake of BP in the femur neck and spine is higher than in the femur shaft $[15,16]$.

\section{Different binding ability}

Competitive bone uptake can occur when two or more BPs are co-administered at high doses [17]. For example, a high concentration of etidronate competes with alendronate binding. Bone uptake may also be influenced by age and gender. The bone turnover rate for modeling and remodeling is age-dependent. Some studies have indicated that the bone turnover rates may differ between young male and female rats, but not older male and female animals [18].

\section{Elimination}

In vivo, only the non N-BPs etidronate and clodronate are metabolized intracellularly to cytotoxic adenosine triphosphate (ATP) analogs; most BPs are not metabolized [19]. BPs are excreted unchanged in urine, as shown by ${ }^{14} \mathrm{C}$-labeled studies. Moreover, active tubular secretion of BPs may also be important [20]. After they attach to bone, BPs are liberated again only when the bone in which they are present is resorbed. They can then be taken up again by the skeleton or released into blood. Some amount of BPs can be further embedded in bone during continued bone formation. Thus, the half-life of BPs in bone depends on the rate of bone turnover $[6,21]$.

\section{Cellular mechanisms of action of BPs Effects on osteoblasts}

Despite the well-documented inhibitory effect of BPs on osteoclasts, increasing attention is being focused on their effects on other effector cells, such as osteocytes and osteoblasts. Several early studies showed that BPs could down-regulate "receptor activator of NF- $\mathrm{KB}$ ligand" (RANKL) and up-regulate osteoprotegerin (OPG) in osteoblasts, which is one mechanism by which BPsindirectly-affect resorption [22-26] (Figure 1). Recent studies have shown that BPs affect the expression of OPG and "macrophage colony-stimulating factor" (M-CSF), both essential in osteoclastogenesis (Figure 1). BPs can increase OPG expression and decrease M-CSF expression; in consequence they might inhibit osteoclastogenesis [25]. Substantial evidence has accumulated that BPs modulate the proliferation and differentiation rates of osteoplastic cells, albeit with varying or conflicting effects, in relation to the concentration of BPs [5,27-31]. BPs can promote the growth and differentiation of osteoblasts at lower concentrations, ranging from $10^{-9}$ to $10^{-6} \mathrm{M}$ but had inhibitory effects at $>10^{-5} \mathrm{M}$ [5].

Previous reports have revealed that enhanced viability of osteocytes and osteoblasts may be involved in the beneficial effects of BPs on bone [32]. Early studies showed that BPs suppressed apoptosis in osteocytes and osteoblasts induced by glucocorticoids in mice [33]. Consistently, alendronate has also been shown to exert an inhibitory effect on osteocyte apoptosis induced by fatigue cyclic loading in rats and mice [33-37]. Thus, increasing attention has focused on this and differing mechanisms of action for the anti-apoptotic effects of BPs have been proposed (Figure 1). Recent studies have suggested that the apoptotic effects of BPs depend strictly on the opening of channels formed by connexin43 (Cx43), a member of the connexin family of proteins expressed in osteoblasts and osteocytes [32,33,36-38]. The opening of Cx43 hemichannels results in the activation of kinases, including Src and "extracellular signal-regulated kinases"(ERKs), which initiates the sequential phosphorylation of the ERKs' cytoplasmic target, p90RSK kinase, and final target substrates, $\mathrm{BAD}$ and $\mathrm{C} / \mathrm{EBP} \beta$, thus suppressing apoptosis [5,33]. Although Cx43 is prerequisite for the prosurvival effect of BPs, recent studies have demonstrated that Cx43 is not required for cell binding of BPs [5,39]. Furthermore, the anti-apoptotic effects of BPs do not depend on inhibitory effects on osteoclasts because analogs that lack anti-resorptive activity could still inhibit apoptosis in osteoblasts and osteocytes without decreasing osteoclast viability [40]. Thus, future studies should address the 


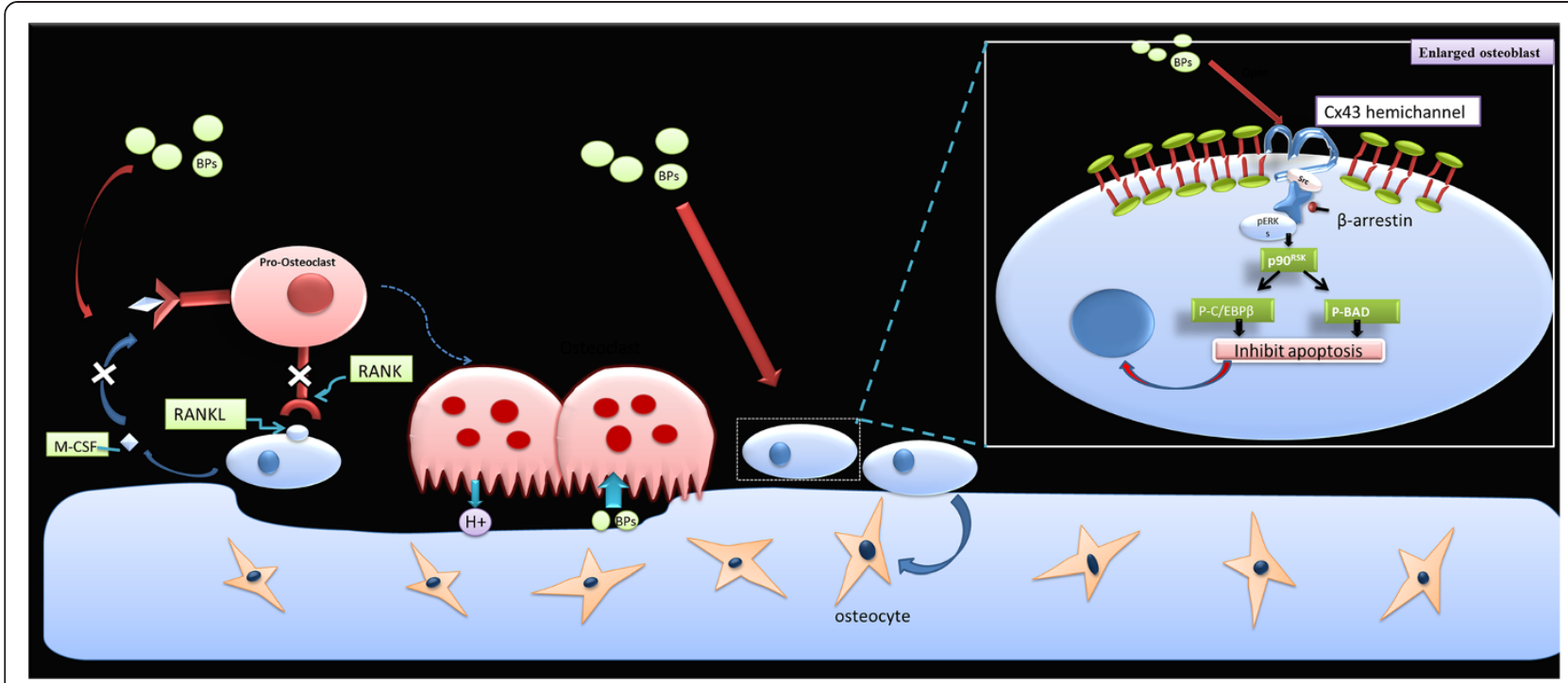

Figure 1 Effects on osteoblasts. BPs can down-regulate "receptor activator of NF-KB ligand" (RANKL) and up-regulate osteoprotegerin (OPG) in osteoblasts, indicating indirect effects on the resorption. BPs can inhibit apoptosis of osteoblasts and osteocytes through Cx43 hemichannels. The opening of Cx43 hemichannels results in the activation of kinases, including Src and "extracellular signal-regulated kinases" (ERKs), which initiates the sequential phosphorylation of the ERK cytoplasmic target, p90RSK kinase, and final target substrates, BAD and C/EBP $\beta$, thus suppressing apoptosis.

binding proteins of BPs and new analogs that do not inhibit bone remodeling.

\section{Effects on osteoclasts}

The significant selectivity of BPs for bone accounts for their efficacy and safety in clinical medicine. Their targeting to bone and their selective uptake by mineral surfaces on bones brings them closely in contact with osteoclasts $[4,41]$. The uptake of BPs by osteoclasts in vivo has been demonstrated using radiolabeling techniques. Previous studies have shown that BPs can affect osteoclast function in various ways, including osteoclast recruitment, differentiation, and resorptive activity, and some may cause apoptosis of osteoclasts [42].

Currently, BPs are classified into two major groups $[4,43,44]$ on the basis of their distinct molecular mechanisms of action (Figure 2). Members of the first group contain a nitrogen atom; members of this group inhibit the mevalonate biosynthetic pathway, which leads to the synthesis of cholesterol and other sterols. Three major isoprenoid lipids produced in the mevalonate pathway are FPP, isopentenyldiphosphate, and geranyl geranyldiphosphate (GGPP). BPs can inhibit farnesyl pyrophosphate synthase (FPPS), the main enzyme in this pathway [45-47]. FPP and GGPP are required for the prenylation of small GTPases, such as Ras, Rab, Rho, and Rac. Loss of GTPases inhibits the formation of the ruffled border, trafficking of lysosomal enzymes, and transcytosis of degraded bone matrix $[48,49]$.

The second group comprises the non-amino-BPs, such as etidronate and clodronate. Members of this group of
BPs can be incorporated metabolically into methylenecontaining analogs of ATP [50]. The metabolite analog of ATP is AppCH2p, which contains the P-C-P moiety of medronate in place of the $\beta, \gamma$ pyrophosphate (P-O-P) moiety of ATP and results in non-hydrolyzable (AppCp) nucleotides [2,51,52]. Furthermore, the accumulation of AppCp-type metabolites of BPs is associated with cytotoxicity [53-55].

\section{Clinical applications of bisphosphonates}

Forty years have now passed since the first description of BPs $[4,56]$. BPs have played an important role in the diagnosis and treatment of various diseases during this period. BPs have become crucial for bone imaging and an important treatment for various diseases, such as osteoporosis, myeloma, bone metastasis, Legg-Perthes disease, malignant hyperparathyroidism, and other conditions involving bone fragility [57]. Most of these diseases are characterized by extensive osteoclast activity.

\section{Bone scans}

According to their diagnostic utility, sensitivity, specificity, and predictive power, BPs were used as agents for bone imaging in the early period. In $1975,{ }^{99 \mathrm{~m}}$ Tc bone imaging agents were found to be a useful diagnostic method $[58,59]$. Today, ${ }^{99 \mathrm{~m}} \mathrm{Tc}$ diphosphonates are used with ${ }^{18} \mathrm{~F}$ fluorodeoxyglucose in metastatic cancer diagnosis because ${ }^{99} \mathrm{~m}$ Tc has an affinity for sites where bone is actively remolded, while ${ }^{18} \mathrm{~F}$ fluorodeoxyglucose is taken up by tumor cells $[60,61]$. 


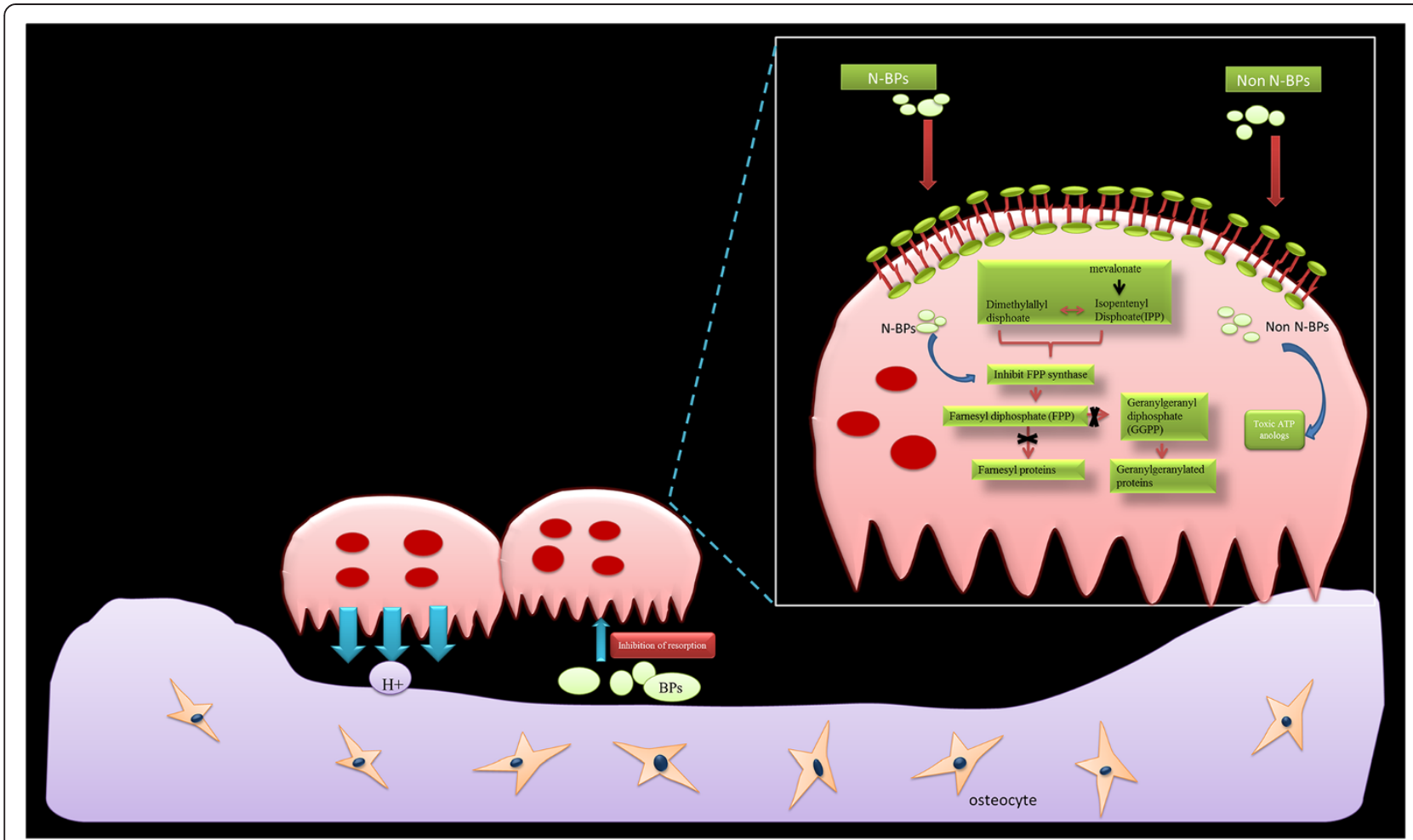

Figure 2 Effects on osteoclasts. Osteoclasts release BPs from the bone matrix. N-containing BPs potently inhibit farnesyl pyrophosphate synthase (FPPS), a key enzyme in the mevalonate/cholesterol biosynthetic pathway. Non-N-BPs are incorporated metabolically into non-hydrolyzable cytotoxic analogs of ATP (AppCp).

\section{Osteoporosis}

Today, BPs are an essential first-line therapy for osteoporosis. Early studies showed that BPs could improve bone mineral density (BMD) and decrease the risk of fracture, especially hip fracture [62-68]. Three BPs, alendronate, risedronate, and ibandronate are most widely used in the clinic. Recently, a potent new bisphosphonate, zoledronic acid, has shown high affinity. It can be taken once per year [69,70], which enhances patient willingness to take the medicine. Some studies showed that zoledronic acid had a dose-dependent cytotoxic effect on odontoblast-like cells under clinical conditions [71], drawing attention to the optimal dose and drug "holidays" with these drugs.

\section{Anti-cancer}

Many kinds of cancers, especially breast, lung and prostate cancers, can metastasize to bone in their disease progression. There are various hypotheses as to how BPs affect tumor cells. Many early studies focused on indirect anti-tumor effects of BPs, the anti-resorptive effects of BPs [72-75]. Recent evidence has shown that BPs can be taken up by other tissues, so they may also have direct effects on tumors [41,76,77]. Some studies showed the BPs could inhibit tumor cell angiogenesis, invasion, proliferation, and survival in vitro. For example, zoledronic acid can downregulate the expression of Bcl-2, an antiapoptotic factor, to induce apoptosis in breast and prostate cancers [76-78]. More recent evidence showed that BPs may inhibit proliferation markers, suppressing the proliferation of tumors [79-84].

\section{Bone inflammation diseases}

Early studies showed that BPs could be used to suppress the lysis induced by glucocorticoids during rheumatoid arthritis (RA) treatment $[85,86]$. Recent studies showed that BPs could inhibit some proinflammatory factors, such as interleukin $1(\mathrm{IL}-1)$, IL-6, and tumor necrosis factor- $\alpha$, [87-91], idicating an anti-inflammatory action of BPs. Also, studies showed that BPs could decrease pain and improve function in osteoarthritis patients [92]. However, the mechanism(s) of these phenomena remain(s) unclear.

\section{Safety}

Despite the widespread use of BPs in the clinic, they have adverse effects, such as gastric irritation, osteonecrosis of the jaw, atypical femoral fractures, esophageal cancer, atrial fibrillation, and ocular inflammation [93].

\section{Upper gastrointestinal tract irritation}

Gastrointestinal irritation is common with oral BPs, and is the most common reason for treatment discontinuation 
[94,95]. Alendronate, an oral nitrogen-containing BP, may cause gastrointestinal symptoms such as dyspepsia, esophagitis, esophageal reflux, and gastritis [96].

\section{Bisphosphonate-related osteonecrosis of the jaw}

Early in the 21st century, the first description of osteonecrosis of the jaw was reported in patients with BP exposure [97]. The adverse effect increased with intravenous injection of BPs [98]. Since then, growing numbers of reports have attempted to describe the effect [65,99-103]. Today, the definition of BRONJ is current or previous treatment with a BP, exposed necrotic bone in the maxillofacial region that has been present for at least 8 weeks, and no history of radiation therapy to the jaws [104,105]. Interestingly, recent studies have shown osteonecrosis of the jaw with the use of denosumab, another antiresorptive drug [106], and bevacizumab [107-110], an anti-angiogenic agent, so the effect may not be specific to BPs. Thus, many researchers have suggested renaming the condition to "drug-associated osteonecrosis of the jaw."

Because of the lack of clarity regarding the mechanism, several hypotheses have made to explain how osteonecrosis of the jaw occurs. However, their discoveries share a common feature, infection. Some consider that bone coated with BPs, especially amino-bisphosphonates increases bacterial adhesion, resulting in bone necrosis and osteomyelitis [111-113]. Others consider that inhibition of bone turnover causes necrosis, then infection occurs [114]. Most recently, a study found that osteonecrosis of the jaw can move to adjacent bone and occur in micro-vascular iliac bone grafts used for reconstruction after a partial mandibulectomy [115]. Thus, more research is needed to determine the mechanism of osteonecrosis of the jaw and the connection with BPs.

\section{Atypical femoral fracture}

Since 2005, increasing numbers of studies of the increased risk of atypical femur fractures in patients taking BPs have been conducted [116-120]. However, later evidence $[121,122]$ showed a lower incidence of atypical femur fractures.

An atypical femoral fracture is located in the femur from just distal to the lesser trochanter to just proximal to the supracondylar flare, associated with no trauma or minimal trauma, a transverse or short oblique configuration, and non-comminuted and complete fractures extending through both cortices with incomplete fractures involving only the lateral cortex [123]. Other features include prodromal pain, increased cortical thickness, bilateral fractures, and delayed healing were also reported [93,124].

How such fractures occur is unknown. Possible mechanisms of BP-related atypical femur fractures include alterations in collagen cross-linking, micro-damage accumulation, increased mineralization, suppression of bone turnover rates, and anti-angiogenic effects [125].

Compared with the considerable benefits of BPs, the incidence of atypical femoral facture is low. Thus, the benefit of continuing therapy may outweigh the possible risk of atypical femoral fracture.

\section{Esophageal cancer}

In 2009, the US Food and Drug Administration reported the development of esophageal cancer in several patients with a history of oral BP use. Since then, four large databases have been analyzed but conflicting results were reached $[114,126,127]$. Three of the studies did not find any increased risk, and one found a dose-dependent increased risk of esophageal cancer. Thus, more data are required to assess causality between BPs and esophageal cancer.

\section{Atrial fibrillation}

An increased incidence of atrial fibrillation was found in the 3-year Health Outcomes and Reduced Incidence with Zoledronic Acid Once Yearly (HORIZON)-Pivotal Fracture Trial of yearly intravenous administration of zoledronate in postmenopausal women with osteoporosis [70]. However, recent studies showed that the risk of atrial fibrillation (AF) or cardiac dysrhythmia was not increased in cancer patients receiving intravenous zoledronic acid [104,128,129]. Moreover, there was no increased risk in postmenopausal women receiving oral alendronate or risedronate [130]. Thus, more effort should be made to discover whether BPs cause an increased risk of atrial fibrillation and, if so, the mechanism(s) of this side effect.

\section{Conclusions}

It is well-established that BPs have become a clinically successful anti-resorptive agent for treating bone disorders. After 40 years of clinical use, the pharmacokinetics of BPs are now clear. They are hardly absorbed through the gastrointestinal lumen, have affinity to the skeleton, and are eliminated slowly. We still have a limited understanding of the cellular mechanism of action of BPs. The biochemical and molecular effects of BPs on osteoclasts can be divided into two distinct mechanisms: direct and indirect. However, the effects on other cell types, such as osteoblast, osteocytes, and monocytes, have not yet been explained fully. Although BPs have been a successful approach to the therapy of bone diseases, exposure to BPs also causes various adverse effects, which have limited their applications. Further studies are required to fully understand the distribution of BPs in extra-skeletal tissues, the effects of BPs on osteocytes, osteoblasts, and monocytes, and to provide new analogs of BPs with fewer limitations in bone turn over and optimal dose 
and routes of administration. In clinical studies, more attention should be paid to the application of BPs in osteoarthritis patients and in inflammatory bone disease.

\section{Abbreviations}

BPs: Bisphosphonates; FPPS: Farnesyl pyrophosphate synthase; RANKL: Receptor activator of NF-KB ligand; OPG: Osteoprotegerin; M-CSF: Macrophage colony-stimulating factor; ERKs: Extracellular signal-regulated kinases; ATP: Adenosine triphosphate; P-O-P: Pyrophosphate; GGPP: Geranylgeranyl diphosphate; BMD: Bone mineral density; RA: Rheumatoid arthritis; AF: Atrial fibrillation; OA: Osteoarthritis; HORIZON: Health outcomes and reduced incidence with zoledronic acid once yearly.

\section{Competing interests}

The authors declare they have no competing interests.

\section{Authors' contributions}

XLX, WLG, YW, QYG, AYW and JP reviewed the literature; XLX, SBL, YW and JP wrote the paper; $X L X, Q L, Q Y G$ proofread the final copy. All authors read and approved the final manuscript.

\section{Acknowledgements}

This work was funded by NSFC (30930092, 31240048, 31170946), NTRDP (2012AA020502, 2012CB518106, BWS11 J025).

Received: 23 July 2013 Accepted: 3 December 2013

Published: 11 December 2013

\section{References}

1. Salari SP, Abdollahi M, Larijani B: Current, new and future treatments of osteoporosis. Rheumatol Int 2011, 31:289-300.

2. Allen MR, Burr DB: Bisphosphonate effects on bone turnover, microdamage, and mechanical properties: what we think we know and what we know that we don't know. Bone 2011, 49:56-65.

3. Cundy T, Reid IR: Paget's disease of bone. Clin Biochem 2012, 45:43-48.

4. Russell RG: Bisphosphonates: the first 40 years. Bone 2011, 49:2-19.

5. Bellido T, Plotkin LI: Novel actions of bisphosphonates in bone: preservation of osteoblast and osteocyte viability. Bone 2011, 49:50-55.

6. Porras AG, Holland SD, Gertz BJ: Pharmacokinetics of alendronate. Clin Pharmacokinet 1999, 36:315-328.

7. Cremers SC, Pillai G, Papapoulos SE: Pharmacokinetics/pharmacodynamics of bisphosphonates: use for optimisation of intermittent therapy for osteoporosis. Clin Pharmacokinet 2005, 44:551-570.

8. Dunn CJ, Goa KL: Risedronate: a review of its pharmacological properties and clinical use in resorptive bone disease. Drugs 2001, 61:685-712.

9. Gertz BJ, Holland SD, Kline WF, Matuszewski BK, Freeman A, Quan H, Lasseter KC, Mucklow JC, Porras AG: Studies of the oral bioavailability of alendronate. Clin Pharmacol Ther 1995, 58:288-298.

10. Fogelman I, Smith L, Mazess R, Wilson MA, Bevan JA: Absorption of oral diphosphonate in normal subjects. Clin Endocrinol (Oxf) 1986, 24:57-62.

11. Gertz BJ, Holland SD, Kline WF, Matuszewski BK, Porras AG: Clinical pharmacology of alendronate sodium. Osteoporos Int 1993, 3(Suppl 3):S13-S16.

12. Monkkonen J, Koponen HM, Ylitalo P: Comparison of the distribution of three bisphosphonates in mice. Pharmacol Toxicol 1990, 66:294-298.

13. Russell RG, Watts NB, Ebetino FH, Rogers MJ: Mechanisms of action of bisphosphonates: similarities and differences and their potential influence on clinical efficacy. Osteoporos Int 2008, 19:733-759.

14. Clezardin P: Bisphosphonates' antitumor activity: an unravelled side of a multifaceted drug class. Bone 2011, 48:71-79.

15. Carnevale V, Dicembrino F, Frusciante V, Chiodini I, Minisola S, Scillitani A: Different patterns of global and regional skeletal uptake of $99 \mathrm{mTc}-$ methylene diphosphonate with age: relevance to the pathogenesis of bone loss. J Nucl Med 2000, 41:1478-1483.

16. Israel O, Front D, Hardoff R, Ish-Shalom S, Jerushalmi J, Kolodny GM: In vivo SPECT quantitation of bone metabolism in hyperparathyroidism and thyrotoxicosis. J Nucl Med 1991, 32:1157-1161.

17. Sato M, Grasser W, Endo N, Akins R, Simmons H, Thompson DD, Golub E, Rodan GA: Bisphosphonate action. Alendronate localization in rat bone and effects on osteoclast ultrastructure. J Clin Invest 1991, 88:2095-2105.
18. Lin JH, Chen IW, Duggan DE: Effects of dose, sex, and age on the disposition of alendronate, a potent antiosteolytic bisphosphonate, in rats. Drug Metab Dispos 1992, 20:473-478.

19. Frith JC, Monkkonen J, Blackburn GM, Russell RG, Rogers MJ: Clodronate and liposome-encapsulated clodronate are metabolized to a toxic ATP analog, adenosine 5'-(beta, gamma-dichloromethylene) triphosphate, by mammalian cells in vitro. J Bone Miner Res 1997, 12:1358-1367.

20. Lin JH: Bisphosphonates: a review of their pharmacokinetic properties. Bone 1996, 18:75-85.

21. Drake MT, Cremers SC: Bisphosphonate therapeutics in bone disease: the hard and soft data on osteoclast inhibition. Mol Interv 2010, 10:141-152.

22. Pan B, Farrugia AN, To LB, Findlay DM, Green J, Lynch K, Zannettino AC: The nitrogen-containing bisphosphonate, zoledronic acid, influences RANKL expression in human osteoblast-like cells by activating TNF-alpha converting enzyme (TACE). J Bone Miner Res 2004, 19:147-154.

23. Viereck V, Emons G, Lauck V, Frosch KH, Blaschke S, Grundker C, Hofbauer LC: Bisphosphonates pamidronate and zoledronic acid stimulate osteoprotegerin production by primary human osteoblasts. Biochem Biophys Res Commun 2002, 291:680-686.

24. Maruotti N, Corrado A, Neve A, Cantatore FP: Bisphosphonates: effects on osteoblast. Eur J Clin Pharmacol 2012, 68:1013-1018.

25. Ohe JY, Kwon YD, Lee HW: Bisphosphonates modulate the expression of OPG and M-CSF in hMSC-derived osteoblasts. Clin Oral Investig 2012, 16:1153-1159

26. Gracis S: Prosthetic and biomechanical factors affecting bone remodeling around implants. Eur J Esthet Dent 2013, 8:314-333.

27. Berglund J: Orthopaedics: Structural support. Nature 2011, 480:S56-S57.

28. Tenenbaum HC, Torontali M, Sukhu B: Effects of bisphosphonates and inorganic pyrophosphate on osteogenesis in vitro. Bone 1992, 13:249-255.

29. Xiong Y, Yang HJ, Feng J, Shi ZL, Wu LD: Effects of alendronate on the proliferation and osteogenic differentiation of MG-63 cells. J Int Med Res 2009, 37:407-416.

30. Im Gl, Qureshi SA, Kenney J, Rubash HE, Shanbhag AS: Osteoblast proliferation and maturation by bisphosphonates. Biomaterials 2004 25:4105-4115

31. Kim HK, Kim JH, Abbas AA, Yoon TR: Alendronate enhances osteogenic differentiation of bone marrow stromal cells: a preliminary study. Clin Orthop Relat Res 2009, 467:3121-3128.

32. Plotkin LI, Manolagas SC, Bellido T: Dissociation of the pro-apoptotic effects of bisphosphonates on osteoclasts from their anti-apoptotic effects on osteoblasts/osteocytes with novel analogs. Bone 2006, 39:443-452.

33. Plotkin LI, Lezcano V, Thostenson J, Weinstein RS, Manolagas SC, Bellido T: Connexin 43 is required for the anti-apoptotic effect of bisphosphonates on osteocytes and osteoblasts in vivo. J Bone Miner Res 2008, 23:1712-1721.

34. Plotkin LI, Manolagas SC, Bellido T: Transduction of cell survival signals by connexin-43 hemichannels. J Biol Chem 2002, 277:8648-8657.

35. Yellowley CE, Li Z, Zhou Z, Jacobs CR, Donahue HJ: Functional gap junctions between osteocytic and osteoblastic cells. J Bone Miner Res 2000, 15:209-217.

36. Lezcano V, Bellido T, Plotkin LI, Boland R, Morelli S: Role of connexin 43 in the mechanism of action of alendronate: dissociation of anti-apoptotic and proliferative signaling pathways. Arch Biochem Biophys 2012, 518:95-102.

37. Watkins MP, Norris JY, Grimston SK, Zhang X, Phipps RJ, Ebetino FH, Civitelli R: Bisphosphonates improve trabecular bone mass and normalize cortical thickness in ovariectomized, osteoblast connexin43 deficient mice. Bone 2012, 51:787-794

38. Jeong HM, Jin YH, Choi YH, Chung JO, Cho DH, Chung MY, Civitelli R, Chung DJ, Lee KY: Risedronate increases osteoblastic differentiation and function through connexin43. Biochem Biophys Res Commun 2013, 432:152-156.

39. Boland RL, Morelli S, Santillan G, Scodelaro P, Colicheo A, de Boland AR, Vyas K, Plotkin LI, Bellido T: Connexin 43 is required for bisphosphonateinduced survival of osteoblastic cells but not for bisphosphonate binding. J Bone Miner Res 2006, 21:S292.

40. Plotkin LI, Bivi N, Bellido T: A bisphosphonate that does not affect osteoclasts prevents osteoblast and osteocyte apoptosis and the loss of bone strength induced by glucocorticoids in mice. Bone 2011, 49:122-127.

41. Cremers S, Papapoulos S: Pharmacology of bisphosphonates. Bone 2011, 49:42-49.

42. Selander KS, Monkkonen J, Karhukorpi EK, Harkonen P, Hannuniemi R, Vaananen HK: Characteristics of clodronate-induced apoptosis in osteoclasts and macrophages. Mol Pharmacol 1996, 50:1127-1138. 
43. Shinoda H, Adamek G, Felix R, Fleisch H, Schenk R, Hagan P: Structureactivity relationships of various bisphosphonates. Calcif Tissue Int 1983, 35:87-99.

44. Russell RG, Croucher PI, Rogers MJ: Bisphosphonates: pharmacology, mechanisms of action and clinical uses. Osteoporos Int 1999, 9(Suppl 2):S66-S80.

45. Amin D, Cornell SA, Perrone MH, Bilder GE: 1-Hydroxy-3(methylpentylamino)-propylidene-1,1-bisphosphonic acid as a potent inhibitor of squalene synthase. Arzneimittelforschung 1996, 46:759-762.

46. Amin D, Cornell SA, Gustafson SK, Needle SJ, Ullrich JW, Bilder GE, Perrone $\mathrm{MH}$ : Bisphosphonates used for the treatment of bone disorders inhibit squalene synthase and cholesterol biosynthesis. J Lipid Res 1992, 33:1657-1663.

47. Soki FN, Li X, Berry J, Koh A, Sinder BP, Qian X, Kozloff KM, Taichman RS, McCauley LK: The effects of zoledronic acid in the bone and vasculature support of hematopoietic stem cell niches. J Cell Biochem 2013, 114:67-78.

48. Coxon FP, Rogers MJ, Crockett JC: Isolation and purification of rabbit osteoclasts. Methods Mol Biol 2012, 816:145-158.

49. Boanini E, Torricelli P, Gazzano M, Fini M, Bigi A: The effect of alendronate doped calcium phosphates on bone cells activity. Bone 2012, 51:944-952.

50. Rogers MJ, Crockett JC, Coxon FP, Monkkonen J: Biochemical and molecular mechanisms of action of bisphosphonates. Bone 2011, 49:34-41.

51. Auriola S, Frith J, Rogers MJ, Koivuniemi A, Monkkonen J: Identification of adenine nucleotide-containing metabolites of bisphosphonate drugs using ion-pair liquid chromatography-electrospray mass spectrometry. J Chromatogr B Biomed Sci Appl 1997, 704:187-195.

52. Rogers MJ, Brown RJ, Hodkin V, Blackburn GM, Russell RG, Watts DJ: Bisphosphonates are incorporated into adenine nucleotides by human aminoacyl-tRNA synthetase enzymes. Biochem Biophys Res Commun 1996, 224:863-869.

53. Green JR: Bisphosphonates: preclinical review. Oncologist 2004, 9(Suppl 4):3-13.

54. Roelofs AJ, Thompson K, Ebetino FH, Rogers MJ, Coxon FP: Bisphosphonates: molecular mechanisms of action and effects on bone cells, monocytes and macrophages. Curr Pharm Des 2010, 16:2950-2960.

55. Roelofs AJ, Thompson K, Gordon S, Rogers MJ: Molecular mechanisms of action of bisphosphonates: current status. Clin Cancer Res 2006, 12:6222s-6230s.

56. Fleisch H, Russell RG, Bisaz S, Casey PA, Muhlbauer RC: The influence of pyrophosphate analogues (diphosphonates) on the precipitation and dissolution. Calcif Tissue Res 1968, suppl:10-10a.

57. Giger EV, Castagner B, Leroux JC: Biomedical applications of bisphosphonates. J Control Release 2013, 167:175-188.

58. Subramanian G, McAfee JG, Blair RJ, Kallfelz FA, Thomas FD: Technetium99 m-methylene diphosphonate-a superior agent for skeletal imaging: comparison with other technetium complexes. J Nucl Med 1975, 16:744-755.

59. Wong KK, Piert M: Dynamic bone imaging with $99 \mathrm{mTc}$-labeled diphosphonates and 18 F-NaF: mechanisms and applications. J NuCl Med 2013, 54:590-599.

60. Brenner Al, Koshy J, Morey J, Lin C, DiPoce J: The bone scan. Seminars in Nuclear Medicine 2012, 42:11-26.

61. Haworth AE, Webb J: Skeletal complications of bisphosphonate use: what the radiologist should know. Br J Radiol 2012, 85:1333-1342.

62. Wells G, Cranney A, Peterson J, Boucher M, Shea B, Robinson V, Coyle D, Tugwell $P$ : Risedronate for the primary and secondary prevention of osteoporotic fractures in postmenopausal women. Cochrane Database Syst Rev 2008, 1:D4523.

63. Bone HG, Hosking D, Devogelaer JP, Tucci JR, Emkey RD, Tonino RP, Rodriguez-Portales JA, Downs RW, Gupta J, Santora AC, Liberman UA: Ten years' experience with alendronate for osteoporosis in postmenopausal women. N Engl J Med 2004, 350:1189-1199.

64. Harris ST, Watts NB, Genant HK, McKeever CD, Hangartner T, Keller M, Chesnut CR, Brown J, Eriksen EF, Hoseyni MS, Axelrod DW, Miller PD: Effects of risedronate treatment on vertebral and nonvertebral fractures in women with postmenopausal osteoporosis: a randomized controlled trial. Vertebral Efficacy With Risedronate Therapy (VERT) Study Group. JAMA 1999, 282:1344-1352.

65. McClung M, Harris ST, Miller PD, Bauer DC, Davison KS, Dian L, Hanley DA, Kendler DL, Yuen CK, Lewiecki EM: Bisphosphonate therapy for osteoporosis: benefits, risks, and drug holiday. Am J Med 2013, 126:13-20.

66. Lai PS, Chua SS, Chan SP: Impact of pharmaceutical care on knowledge, quality of life and satisfaction of postmenopausal women with osteoporosis. Int J Clin Pharm 2013, 35:629-637.
67. Khosla S, Bilezikian JP, Dempster DW, Lewiecki EM, Miller PD, Neer RM, Recker RR, Shane E, Shoback D, Potts JT: Benefits and risks of bisphosphonate therapy for osteoporosis. J Clin Endocrinol Metab 2012 97:2272-2282

68. Lim V, Clarke BL: New therapeutic targets for osteoporosis: beyond denosumab. Maturitas 2012, 73:269-272.

69. Reid IR, Brown JP, Burckhardt P, Horowitz Z, Richardson P, Trechsel U, Widmer A, Devogelaer JP, Kaufman JM, Jaeger P, Body JJ, Brandi ML, Broell J, Di Micco R, Genazzani AR, Felsenberg D, Happ J, Hooper MJ, Ittner J, Leb G, Mallmin H, Murray T, Ortolani S, Rubinacci A, Saaf M, Samsioe G, Verbruggen L, Meunier PJ: Intravenous zoledronic acid in postmenopausal women with low bone mineral density. N Engl J Med 2002, 346:653-661.

70. Black DM, Delmas PD, Eastell R, Reid IR, Boonen S, Cauley JA, Cosman F, Lakatos P, Leung PC, Man Z, Mautalen C, Mesenbrink P, Hu H, Caminis J, Tong K, Rosario-Jansen T, Krasnow J, Hue TF, Sellmeyer D, Eriksen EF, Cummings SR: Once-yearly zoledronic acid for treatment of postmenopausal osteoporosis. N Engl J Med 2007, 356:1809-1822.

71. Basso FG, Turrioni AP, Hebling J, de Souza CC: Effects of zoledronic acid on odontoblast-like cells. Arch Oral Biol 2013, 58:467-473.

72. Reeder DL, Arnold SH, Jeffries LM, McEwen IR: The role of occupational therapists and physical therapists in elementary school system early intervening services and response to intervention: a case report. Phys Occup Ther Pediatr 2011, 31:44-57.

73. Maughan KL, Lutterbie MA, Ham PS: Treatment of breast cancer. Am Fam Physician 2010, 81:1339-1346.

74. Brown SA, Guise TA: Cancer treatment-related bone disease. Crit Rev Eukaryot Gene Expr 2009, 19:47-60.

75. Sun M, lqbal J, Singh S, Sun L, Zaidi M: The crossover of bisphosphonates to cancer therapy. Ann N Y Acad Sci 2010, 1211:107-112.

76. Borutaite V: Mitochondria as decision-makers in cell death. Environ Mo Mutagen 2010, 51:406-416.

77. Clezardin P: Potential anticancer properties of bisphosphonates: insights from preclinical studies. Anticancer Agents Med Chem 2012, 12:102-113.

78. Clezardin P, Benzaid I, Croucher PI: Bisphosphonates in preclinical bone oncology. Bone 2011, 49:66-70.

79. Gnant M, Mlineritsch B, Schippinger W, Luschin-Ebengreuth G, Postlberger S, Menzel C, Jakesz R, Seifert M, Hubalek M, Bjelic-Radisic V, Samonigg H, Tausch C, Eidtmann H, Steger G, Kwasny W, Dubsky P, Fridrik M, Fitzal F, Stierer M, Rucklinger E, Greil R, Marth C: Endocrine therapy plus zoledronic acid in premenopausal breast cancer. N Engl J Med 2009, 360:679-691.

80. Rack B, Juckstock J, Genss EM, Schoberth A, Schindlbeck C, Strobl B, Heinrigs M Rammel G, Zwingers T, Sommer H, Friese K, Janni W: Effect of zoledronate on persisting isolated tumour cells in patients with early breast cancer. Anticancer Res 2010, 30:1807-1813.

81. Diel IJ, Solomayer EF, Costa SD, Gollan C, Goerner R, Wallwiener D, Kaufmann M, Bastert G: Reduction in new metastases in breast cancer with adjuvant clodronate treatment. N Engl J Med 1998, 339:357-363.

82. Powles T, Paterson S, Kanis JA, McCloskey E, Ashley S, Tidy A, Rosenqvist K, Smith I, Ottestad L, Legault S, Pajunen M, Nevantaus A, Mannisto E, Suovuori A, Atula S, Nevalainen J, Pylkkanen L: Randomized, placebocontrolled trial of clodronate in patients with primary operable breast cancer. J Clin Oncol 2002, 20:3219-3224.

83. Diel IJ, Jaschke A, Solomayer EF, Gollan C, Bastert G, Sohn C, Schuetz F: Adjuvant oral clodronate improves the overall survival of primary breast cancer patients with micrometastases to the bone marrow: a long-term follow-up. Ann Oncol 2008, 19:2007-2011.

84. Eidtmann H, de Boer R, Bundred N, Llombart-Cussac A, Davidson N, Neven P, von Minckwitz G, Miller J, Schenk N, Coleman R: Efficacy of zoledronic acid in postmenopausal women with early breast cancer receiving adjuvant letrozole: 36-month results of the ZO-FAST Study. Ann Oncol 2010, 21:2188-2194.

85. Le Goff B, Berthelot JM, Maugars Y, Romas E: Alternative use of bisphosphonate therapy for rheumatic disease. Curr Pharm Des 2010, 16:3045-3052.

86. Suzuki Y: Secondary osteoporosis. Bisphosphonates as a possible strategy for the prevention of bone destruction in rheumatoid arthritis. Clin Calcium 2007, 17:1909-1913.

87. Edwards CJ, Williams E: The role of interleukin- 6 in rheumatoid arthritisassociated osteoporosis. Osteoporos Int 2010, 21:1287-1293.

88. Cantatore FP, Acquista CA, Pipitone V: Evaluation of bone turnover and osteoclastic cytokines in early rheumatoid arthritis treated with alendronate. J Rheumatol 1999, 26:2318-2323. 
89. Hasegawa J, Nagashima M, Yamamoto M, Nishijima T, Katsumata S, Yoshino $S$ : Bone resorption and inflammatory inhibition efficacy of intermittent cyclical etidronate therapy in rheumatoid arthritis. J Rheumatol 2003, 30:474-479.

90. Mazzantini M, Di Munno O, Metelli MR, Bulleri M, Giordani R: Single infusion of neridronate (6-amino-1-hydroxyhexylidene-1,1-bisphosphonate) in patients with active rheumatoid arthritis: effects on disease activity and bone resorption markers. Aging Clin Exp Res 2002, 14:197-201.

91. Maksymowych WP: Anti-inflammatory and immunomodulatory therapies in spondyloarthropathies. Curr Opin Investig Drugs 2000, 1:63-69.

92. Rossini M, Viapiana O, Ramonda R, Bianchi G, Olivieri I, Lapadula G, Adami S: Intra-articular clodronate for the treatment of knee osteoarthritis: dose ranging study vs hyaluronic acid. Rheumatology (Oxford) 2009, 48:773-778.

93. Orozco C, Maalouf NM, et al: Safety of bisphosphonates. Rheumatic diseases clinics of North America 2012, 38:681-705.

94. Takeuchi K, Amagase K: Evaluation of gastric ulcerogenic and healing impairment effects of bisphosphonates: adverse gastric reactions of bisphosphonate. Curr Protoc Toxicol 2012, 21:10-21.

95. Haber SL, MCNatty D: An evaluation of the use of oral bisphosphonates and risk of esophageal cancer. Ann Pharmacother 2012, 46:419-423.

96. Biswas PN, Wilton LV, Shakir SA: Pharmacovigilance study of alendronate in England. Osteoporos Int 2003, 14:507-514.

97. Marx RE: Pamidronate (Aredia) and zoledronate (Zometa) induced avascular necrosis of the jaws: a growing epidemic. J Oral Maxillofac Surg 2003, 61:1115-1117.

98. Ruggiero SL, Mehrotra B, Rosenberg TJ, Engroff SL: Osteonecrosis of the jaws associated with the use of bisphosphonates: a review of 63 cases. J Oral Maxillofac Surg 2004, 62:527-534.

99. Janovska Z: Bisphosphonate-related osteonecrosis of the jaws. A severe side effect of bisphosphonate therapy. Acta Medica (Hradec Kralove) 2012 55:111-115.

100. Saldanha S, Shenoy VK, Eachampati P, Uppal N: Dental implications of bisphophonate-related osteonecrosis. Gerodontology 2012, 29:177-187.

101. Vescovi P, Merigo E, Meleti M, Manfredi M, Guidotti R, Nammour S: Bisphosphonates-related osteonecrosis of the jaws: a concise review of the literature and a report of a single-centre experience with 151 patients. J Oral Pathol Med 2012, 41:214-221.

102. McLeod NM, Brennan PA, Ruggiero SL: Bisphosphonate osteonecrosis of the jaw: a historical and contemporary review. Surgeon 2012, 10:36-42.

103. McLeod NM, Patel V, Kusanale A, Rogers SN, Brennan PA: Bisphosphonate osteonecrosis of the jaw: a literature review of UK policies versus international policies on the management of bisphosphonate osteonecrosis of the jaw. Br J Oral Maxillofac Surg 2011, 49:335-342.

104. Hershman DL, McMahon DJ, Crew KD, Cremers S, Irani D, Cucchiara G, Brafman L, Shane E: Zoledronic acid prevents bone loss in premenopausal women undergoing adjuvant chemotherapy for early-stage breast cancer. J Clin Oncol 2008, 26:4739-4745.

105. Smith MR, Eastham J, Gleason DM, Shasha D, Tchekmedyian S, Zinner N: Randomized controlled trial of zoledronic acid to prevent bone loss in men receiving androgen deprivation therapy for nonmetastatic prostate cancer. J Urol 2003, 169:2008-2012.

106. Stopeck AT, Lipton A, Body JJ, Steger GG, Tonkin K, de Boer RH, Lichinitser M, Fujiwara Y, Yardley DA, Viniegra M, Fan M, Jiang Q, Dansey R, Jun S, Braun A: Denosumab compared with zoledronic acid for the treatment of bone metastases in patients with advanced breast cancer: a randomized, double-blind study. J Clin Oncol 2010, 28:5132-5139.

107. Cummings SR, Schwartz AV, Black DM: Alendronate and atrial fibrillation. N Engl J Med 2007, 356:1895-1896.

108. Karam R, Camm J, McClung M: Yearly zoledronic acid in postmenopausal osteoporosis. N Engl J Med 2007, 357:712-713. 714-715.

109. Lewiecki EM, Cooper C, Thompson E, Hartl F, Mehta D, Papapoulos SE: Ibandronate does not increase risk of atrial fibrillation in analysis of pivotal clinical trials. Int J Clin Pract 2010, 64:821-826.

110. Heckbert SR, Li G, Cummings SR, Smith NL, Psaty BM: Use of alendronate and risk of incident atrial fibrillation in women. Arch Intern Med 2008, 168:826-831.

111. Kobayashi Y, Hiraga T, Ueda A, Wang L, Matsumoto-Nakano M, Hata K, Yatani H, Yoneda T: Zoledronic acid delays wound healing of the tooth extraction socket, inhibits oral epithelial cell migration, and promotes proliferation and adhesion to hydroxyapatite of oral bacteria, without causing osteonecrosis of the jaw, in mice. J Bone Miner Metab 2010, 28:165-175.
112. Ganguli A, Steward C, Butler SL, Philips GJ, Meikle ST, Lloyd AW, Grant MH: Bacterial adhesion to bisphosphonate coated hydroxyapatite. J Mater Sci Mater Med 2005, 16:283-287.

113. Kos M, Junka A, Smutnicka D, Bartoszewicz M, Kurzynowski T, Gluza K: Pamidronate enhances bacterial adhesion to bone hydroxyapatite. Another puzzle in the pathology of bisphosphonate-related osteonecrosis of the jaw? J Oral Maxillofac Surg 2013, 71:1010-1016.

114. Solomon DH, Patrick A, Brookhart MA: More on reports of esophageal cancer with oral bisphosphonate use. N Engl J Med 2009, 360:1789-1790 $1791-1792$.

115. Pautke C, Otto S, Reu S, Kolk A, Ehrenfeld M, Sturzenbaum S, Wolff KD: Bisphosphonate related osteonecrosis of the jaw-manifestation in a microvascular iliac bone flap. Oral Oncol 2011, 47:425-429.

116. Odvina CV, Zerwekh JE, Rao DS, Maalouf N, Gottschalk FA, Pak CY: Severely suppressed bone turnover: a potential complication of alendronate therapy. J Clin Endocrinol Metab 2005, 90:1294-1301.

117. Kwek EB, Goh SK, Koh JS, Png MA, Howe TS: An emerging pattern of subtrochanteric stress fractures: a long-term complication of alendronate therapy? Injury 2008, 39:224-231.

118. Lenart BA, Lorich DG, Lane JM: Atypical fractures of the femoral diaphysis in postmenopausal women taking alendronate. N Engl J Med 2008, 358:1304-1306.

119. Visekruna M, Wilson D, McKiernan FE: Severely suppressed bone turnover and atypical skeletal fragility. J Clin Endocrinol Metab 2008, 93:2948-2952.

120. Aspenberg P, Schilcher J, Fahlgren A: Histology of an undisplaced femoral fatigue fracture in association with bisphosphonate treatment. Frozen bone with remodelling at the crack. Acta Orthop 2010, 81:460-462.

121. Park-Wyllie LY, Mamdani MM, Juurlink DN, Hawker GA, Gunraj N, Austin PC, Whelan DB, Weiler PJ, Laupacis A: Bisphosphonate use and the risk of subtrochanteric or femoral shaft fractures in older women. JAMA 2011, 305:783-789.

122. Schilcher J, Michaelsson K, Aspenberg P: Bisphosphonate use and atypical fractures of the femoral shaft. N Engl J Med 2011, 364:1728-1737.

123. Miller PD, Recker RR, Reginster JY, Riis BJ, Czerwinski E, Masanauskaite D, Kenwright A, Lorenc R, Stakkestad JA, Lakatos P: Efficacy of monthly oral ibandronate is sustained over 5 years: the MOBILE long-term extension study. Osteoporos Int 2012, 23:1747-1756.

124. Allison MB, Markman L, Rosenberg Z, Vieira RL, Babb J, Tejwani N, Peck V: Atypical incomplete femoral fractures in asymptomatic patients on long term bisphosphonate therapy. Bone 2013, 55:113-118.

125. Lewiecki EM: Safety of long-term bisphosphonate therapy for the management of osteoporosis. Drugs 2011, 71:791-814.

126. Green J, Czanner G, Reeves G, Watson J, Wise L, Beral V: Oral bisphosphonates and risk of cancer of oesophagus, stomach, and colorectum: case-control analysis within a UK primary care cohort. BMJ 2010, 341:C4444

127. Abrahamsen B, Eiken $P$, Eastell R: More on reports of esophageal cancer with oral bisphosphonate use. N Engl J Med 2009, 360:1789. 1791-1792.

128. Lyles KW, Colon-Emeric CS, Magaziner JS, Adachi JD, Pieper CF, Mautalen C, Hyldstrup L, Recknor C, Nordsletten L, Moore KA, Lavecchia C, Zhang J, Mesenbrink, Hodgson PK, Abrams K, Orloff JJ, Horowitz Z, Eriksen EF Boonen S: Zoledronic acid in reducing clinical fracture and mortality after Hip fracture. N Engl J Med 2007, 357:a40967.

129. Bundred NJ, Campbell ID, Davidson N, DeBoer RH, Eidtmann H, Monnier A, Neven P, von Minckwitz G, Miller JC, Schenk NL, Coleman RE: Effective inhibition of aromatase inhibitor-associated bone loss by zoledronic acid in postmenopausal women with early breast cancer receiving adjuvant letrozole: ZO-FAST Study results. Cancer 2008, 112:1001-1010.

130. Lamberg AL, Horvath-Puho E, Christensen S, Sorensen HT: Use of oral bisphosphonates and risk of venous thromboembolism: a populationbased case-control study. Osteoporos Int 2010, 21:1911-1917.

\section{doi:10.1186/1479-5876-11-303}

Cite this article as: Xu et al.: Basic research and clinical applications of bisphosphonates in bone disease: what have we learned over the last 40 years?. Journal of Translational Medicine 2013 11:303. 